\title{
AN ESSAY ON JURISDICTION, JURISPRUDENCE, AND AUTHORITY: THE HIGH COURT OF AUSTRALIA IN YORTA YORTA (2001)
}

\author{
Shaunnagh Dorsett, Senior Lecturer, Faculty of Law, Victoria \\ University of Wellington and Shaun McVeigh, Senior Lecturer, \\ Faculty of Law, Griffith University \\ INTRODUCTION
}

Like the common law legal ordering of England and Wales, the ordering of British colonisation has, in many ways, been an affair of jurisdiction. It is through jurisdiction that the authority of the common and imperial laws have been asserted, and it is through questions of jurisdiction that the legal settlement of the colonies has been effected. Post-colonising and postcolonial settlements have frequently turned to constitutional orders to reconstitute normative relations between the conceptual register of nation (state)-sovereignty-territory and that of land and people. However, questions of jurisdiction remain. This is nowhere more so than in Australia where there has been no attempt at constitutional transformation. One consequence of this is that relations between indigenous law and common law of Australia continue and repeat the first colonial encounters. This essay figures jurisdiction as central to the question of the legal settlement of the land of Australia and follows the way in which questions of jurisdiction continues to give shape to those of authority, sovereignty and jurisprudence - and so to accounts of the responsibility of law.

At its broadest, jurisdiction is taken here as referring to the power and authority to speak in the name of the law. ${ }^{1}$ It encompasses the authorisation and ordering of law as such and not simply determinations of authority within a legal regime. While such questions of jurisdiction can be addressed at the level of normative justification, in this essay attention is paid to the acts of authorisation, differentiation and representation that both distinguish law from non-law and provide the means of government through law. Concentration on these latter aspects of jurisdiction draws attention to the manner of the representational and technical ordering of the legal domain rather than doctrinal or ethical critique. It is with the broad range of devices through which the ordering of law comes to be represented rather than the specific doctrinal and administrative ordering of native title jurisprudence that this essay is concerned. ${ }^{2}$ What is addressed in this essay is the manner in which the High Court represents itself as exercising its own jurisdiction.

In order to draw out what is at issue in maintaining the centrality of questions of jurisdiction, this essay examines of the decision of the

1 This definition is taken from Peter Rush. See P. Rush, "An Altered Jurisdiction: Corporeal Traces of Law", (1997) 6 G.L.R. 144, 150.

2 See generally, P. Goodrich, Y. Hachamovitch, "Time out of Mind: An Introduction to the Semiotics of the Common Law" in P. Fitzpatrick, Dangerous Supplements: Resistance and Renewal in Jurisprudence (1991). 
Australian High Court in Yorta Yorta, one of its more recent judgments on Native Title. ${ }^{3}$ In Yorta Yorta the High Court has continued the elaboration of the legal conditions of the acquisition of the territory and land of what is now Australia that it began over a decade ago in Mabo (No.2). ${ }^{4}$ The central conceptual, and jurisdictional, concern of the judgment in Yorta Yorta was the way in which "traditional laws and customs intersect with the common law". ${ }^{5}$ The difficulty or problem with which the High Court presented itself can be represented emblematically in the way that the majority tried to hold on to the recognition of an 'intersection' of laws (or at least of normative orders) whilst at the same time refusing to recognise any possibility of there being a 'parallel' ordering of laws - indigenous or otherwise. The judgments in Yorta Yorta struggled, often elliptically, with how these two claims of legal ordering might be put into relation. It will be argued here that it is with questions of jurisdiction that this central issue of native title jurisprudence in Yorta Yorta can be most sharply addressed. (It is the failure of the High Court to provide much of an account of its own jurisdiction and jurisprudence that has obscured both the conditions of existence and operation of any such intersection of laws and the possibilities of responsibility for law.)

In Part One, the decision in Yorta Yorta is outlined and it is shown how questions of native title and legal tradition are linked to those of jurisdiction; in Part Two attention is turned to the particular use of jurisprudence made by the majority of the High Court and the way that it establishes links in the judgment between sovereignty, jurisdiction and custom; and in Part Three consideration will be given to the accounts of authority and the ethic of responsibility practiced by the High Court. At each point the judgment is turned to its representation of jurisdiction. ${ }^{6}$

3 Members of the Yorta Yorta Community v Victoria (2002) 194 A.L.R. 538 (HCA). ${ }_{4}$ Mabo v State of Queensland (No.2) (1992) 175 C.L.R. 1 [hereafter Mabo (No.2)].

5 Yorta Yorta, above n.3, 548.

6 While much has been written on native title, little of this corpus considers questions of jurisdiction and representation. For the three articles that do concern jurisdiction see S. Dorsett, "Since Time Immemorial': A Story of Common Law Jurisdiction, Native Title and the Case of Tanistry", (2002) 26 Melb. Uni LR 32, P. Rush, "An Altered Jurisdiction: Corporeal Traces of Law", above n.1, S. Dorsett, S. McVeigh, "Just So: "The Law Which Governs Australia is Australian Law" (2002) 13 Law and Critique 289. For accounts which consider in some way the relationship between native title and the common law/Australian nation see, for example, Fejo v Northern Territory (1998) 195 CLR 96, 128; N. Pearson, "The Concept of Native Title at Common Law" in G. Yunupingu (ed), Our Land is Our Life: Land Rights - Past, Present and Future (1997), 154; N. Pearson, "Principles of Communal Native Title", (2000) 5 Indigenous Law Bulletin 4; L. Strelein, "Conceptualising Native Title", (2001) 23 Sydney Law Review 95. For general works on native title see the Special Edition of Law and Critique marking the $10^{\text {th }}$ anniversary of the decision in Mabo (No.2): (2002) 13 Law and Critique and the Special Issue of the Australian Feminist Law Journal, entitled "Divining the Source: Law's Foundation and the Question of Authority": (2003) 19 AFLJ. For works which discuss other facets of Yorta Yorta see A. Reilly, "From a Jurisprudence of Regret to a Regrettable Jurisprudence: Shaping Native Title from Mabo to Ward", (2002) 9 E-law 1; L. Strelein, "Members of the Yorta Yorta Aboriginal Community v Victoria [2002] HCA 58 (12 December 2002): Comment" (2003) 2(21) Land, Rights, Laws : Issues Of Native Title 1, S. Young, 


\section{Native Title and The Decision in Yorta Yorta}

Until 1992, the common law of Australia did not recognise the doctrine of aboriginal rights. In this respect, Australia lagged significantly behind other jurisdictions, such as Canada, New Zealand and the United States, in which courts had already begun to the task of reconciling indigenous rights to land with colonial regimes. ${ }^{7}$ In Mabo (No.2), the High Court held that while the acquisition of sovereignty over the Australian continent was non-justiciable, it could consider the domestic consequences of that acquisition, and that a form of indigenous rights to land could be recognised at common law. The rights and interests recognised by the common law were to be known as 'native title'. In the twelve years since the initial recognition of native title in Mabo (No.2), there has been significant litigation with respect to technical issues of the scope and nature of native title rights, and the extinguishment of those rights. ${ }^{8}$ Regardless of the questions before the High Court in these cases, however, at the heart of each lies a concern with delimiting relations between the rights of Indigenous Australians and those of the colonising power. For the High Court, what seems to be at stake is the sovereign authority of the Australian Nation. While glimpses of this concern can be seen in earlier determinations of the High Court, it is only in the recent decision in Yorta Yorta that the High Court finally attempts to provide an account of the relations between sovereignty, the common law and indigenous law.

Yorta Yorta concerned an application for a determination of native title with respect to an area which straddled the New South Wales/Victorian border. The Yorta Yorta commenced their claim in 1994, and it was one of the first claims lodged under the Native Title Act. ${ }^{9}$ Section 223(1) of the Act defines native title, and much of the argument before all courts centred around the correct interpretation of this section and in particular of the word 'traditional'. The relevant section states that native title is "communal ... rights and interests ... where (a) the rights and interests are possessed under the traditional laws acknowledged, and the traditional customs observed, by the Aboriginal peoples. ..." The word 'traditional' in this subparagraph raised questions as to what did it mean for laws and customs to be 'traditional'? How much could they change or 'evolve'? What evidence was required of their transmission across the generations?

"The Trouble with 'Tradition': Native Title and the Yorta Yorta Decision" (2001) 30 UWALR 1. K. Anker, "Law in the Present Tense: Tradition and Cultural Community in Members of the Yorta Yorta Aboriginal Community v Victoria (2004) MULR 1

7 See, inter alia, Johnson v M'Intosh 8 Wheat. 543, 21 U.S. 543 (1823), Cherokee Nation v Georgia, 5 Pet. 1, 30 U.S. 1 (1831), Worcester v Georgia, 6 Pet. 515, 31 U.S. 515 (1832), The Queen (on the prosecution of McIntosh) v Symonds (1847) N.Z.P.C.C. 387, Te Runanganui o Te Ika Whenua Inc Society v Attorney-General [1994] 2 NZLR 20 and most recently Ngati Apa, Ngati Koata v Ki Te Tau Ihu [2003] 3 N.Z.L.R. 643, R. v Delgamuuwk v British Columbia (1997) 153 D.L.R. $\left(4^{\text {th }}\right) 193$.

8 See, for example, The Wik Peoples v State of Queensland (1996) 187 CLR 1, Fejo v Northern Territory (1998) 195 CLR 96, Commonwealth v Yarmirr (2001) 184 A.L.R. 113, Ward v Western Australia (2000) 191 A.L.R. 1.

9 Native Title Act 1993 (Cth). 
At first instance, Olney $\mathbf{J}$ found that native title did not exist on the grounds that native title had been extinguished by reason of loss of connection with the land. In so deciding, of crucial importance was the issue of the extent to which the Yorta Yorta still observed their traditional laws and customs. In order to succeed it was necessary for the Yorta Yorta to show that they were still a 'traditional society'. To prove this what was required was an historical account of the laws and customs of the Yorta Yorta at the time of European contact. Native title could only survive if these laws and customs continued to be observed by the claimants. ${ }^{10}$ According to Olney J, the Yorta Yorta were unable to demonstrate that their contemporary practices demonstrated a continuous link back to the laws and customs of the original inhabitants. Thus, these practices did not have "the character of traditional laws acknowledged and traditional customs observed" as required by the common law and statutory definitions of native title. ${ }^{11}$ As a result, their title had been 'washed away' by the 'tide of history'. ${ }^{12}$

The Majority of the Federal Court of Appeal, Beaumont and Katz JJ upheld the trial judge's decision, but in so doing rejected the so-called 'frozen rights' approach, according to which rights remain frozen in time, unable to evolve or change in response to white culture and laws. While Black C.J. dissented, holding that Olney $\mathbf{J}$ had erred in applying too restrictive an approach to the concept of 'traditional', all members of the court were in substantial agreement that the traditional laws and customs that form the foundation for native title may adapt and change. The majority stated that:

"The test of whether a law acknowledged, or a custom observed, is a traditional law or custom is . . . principally an objective test. The primary issue is whether the law or custom has in substance been handed down from generation to generation; that is, whether it can be shown to have its roots in the tradition of the relevant community."13

As with the courts below, the High Court's judgment centred on the meaning of 'tradition'. Both the majority and the minority proceeded from an understanding that native title constitutes the point of intersection between two laws, or normative systems: aboriginal law and common law. ${ }^{14}$ Therefore, "[a]n application for determination of native title requires the location of that intersection, and it requires that it be located by reference to the Native Title Act". ${ }^{15}$ As put by the majority, "it is critically important to identify what exactly it is that intersects with the common law. Is it a body of traditional law and custom as it existed at the time of sovereignty? Is it a body of law and custom as it exists today but which, in some way, is connected with a body of law and custom that existed at sovereignty?"16

10 Members of the Yorta Yorta Community v Victoria [1989] FCA 1606, [3-5].

11 ibid., [128].

12 ibid., [126]. For an interesting critique of Olney J's decision see V. Kerruish, C. Perrin, "Awash in Colonialism", (1999) 24 Alt. L.J. 3.

13 Members of the Yorta Yorta Community v Victoria (2001) 180 A.L.R. 655, 688 (FFC).

14 Yorta Yorta (HCA), above n.1, quoting from Fejo v Northern Territory (1998) 195 CLR 96, 128.

15 ibid.

16 ibid., 549. 
However, as will be seen, the majority and minority disagreed on what might be termed the spatial and temporal logics of native title.

For the majority, the key point of departure lay, and continues to lie, with the assertion of sovereignty by the British Crown. It is because of the nature of sovereignty that the rights and interests recognised in land must be related to those that existed before assertion of sovereignty by the British Crown. As such the majority position can be summarised:

"The native title rights and interests which are the subject of the Act are those which existed at sovereignty, survived that fundamental change in legal regime, and now, by resort to the processes of the new legal order, can be enforced and protected. It is those rights and interests which are 'recognised' in the common law."17

For the Majority, although there are two normative systems one must be dominant. The logic of state sovereignty requires this. Further there can be no 'parallel law-making':

"Upon the Crown acquiring sovereignty, the normative or lawmaking system which then existed could not thereafter validly create new rights, duties or interests. Rights or interests in land created after sovereignty and which owed their origin and continued existence only to a normative system other than that of the new sovereign power, would not and will not be given effect by the legal order of the new sovereign." 18

Since rights and interests created by indigenous normative systems after sovereignty cannot be given effect to, traditional laws and customs, and hence native title, must irrevocably be tied to pre-sovereign practices. The result for the interpretation of section 233 Native Title Act is that the meaning of 'traditional laws and customs' is constrained to include only those laws and customs which can be sourced in a pre-sovereign normative system. This does not, of course, necessarily lead to any implication that custom cannot change or 'adapt' over time. It does, however, for the majority entail evidence of transmission of a 'body of law' (rather than specific customs) from generation to generation:

"When the society whose laws or customs existed at sovereignty ceases to exist, the rights and interests in land to which these laws and customs gave rise, cease to exist. If the content of the former laws and customs is later adopted by some new society, those laws and customs will then owe their new life to that other, later, society and they are the laws acknowledged by, and customs observed by, that later society, they are not laws and customs which can now properly be described as being the existing laws and customs of the earlier society. The rights and interests in land to which the readopted laws and customs give rise are rights and interests

17 ibid., 560-1.

18 ibid., 552. 
which are not rooted in pre-sovereignty traditional law and custom but in the laws and customs of the new society." 19

For the majority, the inquiry to be made is as to "the relationship between the laws and customs now acknowledged and observed, and those that were acknowledged and observed before sovereignty, and to do so by considering whether the laws and customs can be said to be the laws and customs of the society whose laws and customs are properly described as traditional laws and customs." 20

For the Kirby and Gaudron JJ (in dissent), questions of sovereignty and the intersection of laws were treated in a somewhat different manner. However, the question of the continuity of community was also important: "[c]ontinuity, including continuity of community, is a matter that bears directly on the question whether present day belief and practices can be said to constitute acknowledgement of traditional laws and observance of traditional customs." 21 It is not, however, in of itself a pre-requisite for a determination of native title. Continuity was inherent in the word 'traditional'. Quoting from the Macquarie and Oxford Dictionaries:

"As a matter of ordinary usage, the word "traditional" does not necessarily signify rigid adherence to past practices. Rather, it ordinarily signifies that that which it describes has been handed down from generation to generation, often by word of mouth." 22

For the Gaudron and Kirby JJ, this meant that in order for laws and customs to be identified as traditional "they should have their origins in the past and, to the extent that they differ from past practices, the differences should constitute adaptations, alterations, modifications or extensions made in accordance with the shared values or the customs and practices of the people who acknowledge and observe those laws and customs." 23 Continuity is, therefore, a question of fact. Groups may disperse and regroup. ${ }^{24}$ The real question is whether "there have been persons who have identified themselves and each other as members of the community in question." 25

Callinan J also looked to the dictionary definition of 'traditional'. According to Callinan J, 'traditional' requires a high degree of continuity, ". . . intergenerational transmission, acknowledgement and observance." 26 Like Gaudron and Kirby JJ, Callinan $\mathbf{J}$ does not refer to the problem or even possibility of parallel laws. In fact, his judgment provides little guidance as to how change and modification is to be considered by the court. $\mathrm{He}$ suggested that either of two approaches were possible. One could "start with the situation then and trace the development until now with due regard to the evolutions of the traditions in question." Or "it may well be possible to start

19 ibid., 554.

20 ibid., 555.

21 ibid., 568.

22 ibid., 568-9.

23 ibid., 569.

24 ibid., 570.

25 ibid.

26 ibid., 591. 
with the present and look backwards to see if the former is in truth a current manifestation of the latter." 27 However, while Callinan J does not deny that change can occur, it appears that his Honour would not be willing to allow much change before a custom or law was no longer 'traditional'. Some guidance as to his approach may be gleaned from the following:

"The matter [of how far custom may evolve] went uncontested in Yanner v Eaton, although I myself may have questioned whether the use of a motorboat powered by mined and processed fuel, and a steel tomahawk, remained in accordance with a traditional law and custom, particularly one of alleged totemic significance." ${ }^{28}$

McHugh contented himself with saying that he continued, as he had in Yarmirr, to disagree with the approach of the majority to both the source of the definition of native title and the scope of recognition, but that the appeal should fail as there was no error of law on the part of the trial judge. ${ }^{29}$

In sum the tests of 'traditionality' are used by the High Court as a threshold for the recognition of aboriginal laws and customs. In this respect at least the High Court uses the Native Title Act as a device to establish the conditions for the recognition of other laws and customs as well as the exercise of its own jurisdiction. For the majority this question of jurisdiction is determined once and for all with the assertion of sovereignty by the British Crown. There is only one intersection of laws, and only be one law of the territory. For the minority the question of recognition of traditional laws and customs is to be determined in the present. The minority did not feel the need to address questions about their own jurisdiction. The interpretation of the term 'traditional' appears to have been established by the criteria 'ordinary' language. While of course reference to dictionary meanings is an established aid to statutory interpretation, such interpretation remains set within a legal ordering of meaning. It is this ordering of jurisdiction that is addressed in the next section.

\section{Jurisprudence and Jurisdiction}

As with the decision in Mabo (No.2) a bare summary misses much of the force of the judgment. At the centre of its discussion of tradition lie a number of threshold disputes about sovereignty, authority and territorial legal order that circulate around the question of the jurisdiction of the law of Australia. In order to reveal these disputes, we now turn to consider how the majority establish sovereignty as the criteria for the intersection of laws and how questions of jurisdiction come to be represented.

Rhetorically, the majority decision in Yorta Yorta is striking for taking up a University jurisprudence - the positivism and analytical language philosophy of 'Oxford Jurisprudence' - to give form to its deliberations. At issue here is not so much the continued merit of the jurisprudence deployed, but more the uses to which this body of work is put in the judgment. For all that the Majority advises the reader that such work should be treated with great

27 ibid., 591-2.

28 ibid., 592.

29 ibid., 572. 
caution, as indeed the reader should, their disavowals did not prevent them from using it to perform a number of tasks within the judgment.

'Oxford jurisprudence', it might be recalled, started out in the nineteen fifties by developing semantic accounts of the ordinary use of legal language. Its major innovation was to equip the language of positivist jurisprudence with ways to re-describe the practices of municipal or state law. For Herbert Hart such accounts were to be considered more clarificatory than normative in aspiration. ${ }^{30}$ The clarification, as practiced by Hart, generally consisted in analysing the ways in which legal discourse related to wider forms of social and ethical life. ${ }^{31}$ Hart's analysis of legal practices centred on two ways of delimiting law. The first was the elaboration of sovereign authority in terms of the recognition practices of legal officials and the functioning of institutional systems of rules. ${ }^{32}$ The second, equally important, was the delimitation of the context in which these descriptions of rule were established. The first context set for the recognition of law was the movement from pre-legal systems into mature, civilized, legal systems. For Hart this context was 'genetic' or speculative and in this Hart followed a long tradition of Enlightenment jurisprudence that explained the present by means of a progressive 'evolutionary' history. ${ }^{33}$ As others have pointed out the temptation to treat genetic arguments as factual history has bedevilled modern jurisprudence. ${ }^{34}$ The second context, more obliquely, was the historical move from colonial to post-colonial legal orders.

For the majority in Yorta Yorta the clarification of Oxford jurisprudence was deployed to explain how to take into account 'some fundamental principles' in relation to the 'recognition' of native title rights and the 'normative systems' that pre-dated and survived the Crown's acquisition of sovereignty and radical title. ${ }^{35}$ In brief the majority in Yorta Yorta employed Hart's jurisprudence as a guide to the mastery of the social practices and rules of recognition of its own law, and hence the recognition of other laws. ${ }^{36}$

The lesson that the majority were keen to transmit through jurisprudence was how what it called two cardinal facts should be understood:

"[f]irst, [that] the laws and customs and the society which acknowledges and observes them are inextricably interlinked. Secondly, [that] one of the incontestable consequences of the change in sovereignty was that the only native title rights or interest in relation to land or waters which the new sovereign order recognised were those that existed at the time of change in sovereignty." ${ }^{37}$

30 H.L.A. Hart., The Concept of Law (2 $2^{\text {nd }}$ ed. 1994), "Introduction".

31 ibid., Ch. 1.

32 ibid., Ch. 6.

33 ibid., Ch. 5; P. Stein, Legal Evolution: The Story of an Idea (1980).

34 The move from pre-legal to legal order is genetic in the sense that it is speculative or heuristic rather than a historical reality or fact. See, for example, P. Fitzpatrick, The Mythology of Modern Law (1992).

35 Yorta Yorta (HCA), above n.3, 550.

36 ibid., 551.

37 ibid., 555. 
It is precisely the incontestable quality of these facts and their meaning that was in dispute in Yorta Yorta. In this section a number of links between the 'intersection of laws' and jurisdiction are followed: first, through the linking questions of the imbrication of law and custom with the order of sovereignty; and then, second, through the way in which disputes in common law about questions of jurisdiction have become facts and evidence. Finally, consideration is given to the consequences of these gestures for the representation of 'parallel' laws (or at least of the representation of the impermissibility of parallel laws).

\section{Sovereignty}

Questions of sovereignty and possession continue to vex all claims of native title. Despite their claims that any examination of native title must proceed from the Native Title Act, it is clear that the majority commenced with the consequences of sovereignty, and that their views on sovereignty coloured subsequent interpretations of the provisions of the Act.

In Yorta Yorta the narrative of sovereignty was presented in stark terms. The assertion of sovereignty by the British Crown 'necessarily entailed' that thereafter there could be "no parallel law-making system in the territory over which it asserted sovereignty. To hold otherwise would be to deny the acquisition of sovereignty and . . that is not permissible." 38

Thus, for the majority there is an inevitable link, or a 'necessary entailment', between sovereignty, legal system and territory. The status of this 'necessary entailment' is not easy to establish. On the one hand it might be a statement of law, albeit one that is made without reference to any direct authority. On the other hand the claim could be understood as being of a logical or axiomatic nature. The assertion of sovereignty, and the authority of law, it might be thought from the above, can only be accomplished in terms of an absolute (legal) occupation/dominion of a territory. Sovereignty is a matter of authority, and of submission to authority, and it is inextricably linked to territory. While it is clear, to the majority, that no parallel-law making system can survive, it is not so clear what kind of intersection of normative orders can be managed in the aftermath of such recognition.

A beginning can be made by examining how the majority of the High Court deliver their account of sovereignty. In the Concept of Law, Hart takes up the question of the recognition (or permission) of sovereignty by seeking a relation between legal discourse and other forms of social and political practice. For the most part Hart takes for his examples the conventional (empirical) 'recognition practices' of officials and presents legal order as a socio-logic of acts of state. ${ }^{39}$ Many have noted the somewhat paradoxical, self-authorising, form this account of sovereignty takes: those who do the recognising are only authorised to do so by the system they recognise. Such formulations also commit legal officials (such as judges) to the government

38 ibid., 552.

39 Hart's discussion of Sovereignty is analytical. The rule of recognition overcomes what Hart views as the formal weakness of John Austin's account of law, viz: (i) problems of temporality and (ii) fictions of consent. The introduction of the rules of recognition allows Hart to explain the transmission or inheritance of law. See Hart, above n.30, Ch. 6. 
of what is or is not to be recognised. For Hart, and the High Court, this act of government is predominantly temporal and functional. In one aspect these acts of government are a formal corollary of the recognition practices: legal officials recognise their law. But the temporal ordering of laws also arises from a decision about how to recognise laws. This organisation of the boundaries of jurisdiction could be arranged in any way that marks a boundary or limit of law. For Hart this question is answered speculatively in the genetic transition from the pre-legal (or primitive) orders to mature or civilised legal orders. ${ }^{40}$ One system of laws takes the place of, or succeeds, another. But such borders could be arranged differently, for example as a juxtaposition of laws, or as parallel laws. Abstract as Hart's formulations of sovereignty and legal order might be, they can be taken, both within Hart's jurisprudence and that of the majority of the High Court in Yorta Yorta, as articulating a set of social practices. Such practices of law have their own time and place. Not only do the practices of sovereignty have a history, but so too does the concept of sovereignty.

One significant attempt to give a historical understanding of political-legal sovereignty can be found in the historical jurisprudence of Carl Schmitt. ${ }^{41}$ For Schmitt, the political and legal form of sovereignty received its decisive formulation in the seventeenth century. In this formulation, sovereignty is tied to territory, and exercised over a definite people. Chief amongst the objectives of nation state formation was the ending the sectarian wars of religion. The Treaty of Westphalia in 1648 has often been treated as the political culmination of this project. The Treaty was one of the first instruments to embody the links between the emerging notions of sovereignty and of territory. Concluded to end the thirty years war, the Holy Roman Emperor gave sovereign independence to princes who remained formally within the empire, and guaranteed the inviolable nature of state territory. By the end of the eighteenth century, "the notion of national sovereignty over well-defined territory had come to the fore in political practice as well as in the theory of jurisprudence." 42 The legal form of the political notion of territorial sovereignty could be found in the jurisprudence of jus publicum Europaeum. Its jurisprudential elaboration centred on a tradition of state directed civil jurisprudence initiated in the work of Hobbes, Grotius, and Pufendorf. ${ }^{43}$ This political-legal settlement of European territorial states also provided for the colonisation of the rest of the world. For present purposes two points are worth noting. First that these accounts represent the State as in need of no further justification beyond that of reason of State. This is so not simply because of an intrinsic axiomatics, but

40 Despite Brennan J's assertion that such questions of civilisation have been removed from common law thought, it has continued to prove difficult for the common law to think with out such a terminology. For an argument that Brennan J himself continued to argue through the language of civilisation see H. Patapan, Judging Democracy: The New Politics of the High Court (2000).

41 C. Schmitt, "The Land Appropriation of a New Word", (translation of Chapter II, "Die Landnahme einer neuen Welt", in Der Nomos der Erde im Völker echt der Jus Publicum Europeaeum, (2 ${ }^{\text {nd }}$ ed. 1974, originally published (1950)), (1996) 109 Telos 29.

42 J. Gottman, The Significance of Territory (1973), p.17.

43 For a further discussion of Schmitt in this context see S. Dorsett, S. McVeigh, "Just So: 'The Law Which Governs Australia is Australian Law" above n.6. 
because of the particular political legal formulation of the State. Second, the link between sovereignty and territory was an integral part of the politicallegal settlement of Europe and then the colonies.

For the majority in Yorta Yorta the temporal aspects of sovereignty remain beyond question. The link between sovereignty and recognition clearly relates questions of sovereignty to those of authority or jurisdiction of the Court. It is the sovereign that has the authority to recognise interests in land. Where there is a change of, or acquisition of, sovereignty, only the new sovereign can recognise such interests, including native title. The spatial aspects of sovereignty and its relation to territory receive less direct attention. This may be because, for them, it also remains beyond legal dispute: sovereignty and territory are irrevocably tied together as a jurisdiction. The particular spatial formulation of the territorial state also has a particular history, Schmitt, for example, points to the way the seventeenth century political settlement of Europe involved its 're-spatialisation' into sovereign territorial states. The State became territorial - and based on the appropriation of land - because it was concerned to defend a specifiable population. Outside of the land-based states of Europe, the New World was deemed ready for acquisition through the assumption of land. ${ }^{44}$ It is the colonial project, centred on the appropriation of land, that links sovereignty and territory to land. Sovereignty and territory became geographically inseparable with the land of the new colony. This involved the imposition of one law (the common law) figuratively and spatially on top of an other (indigenous law). ${ }^{45}$ In Brennan J's terms, the common law became the "law of the territory". ${ }^{46}$

If there can be no parallel-law making, so what then, if anything, is left of the old law? As will be seen in the next section, if there is no law, then in the common law formulation (as well as that of Hart) all that remains is 'custom'.

\section{Custom and Law}

Recognition of customs and traditional laws is central to the native title regime. In decisions since Mabo (No.2) it has become apparent to the Courts that what is being engaged is indeed another normative order - however it is understood. What was in dispute in Yorta Yorta was the criteria, the time, and the place of this intersection or recognition. What is clear is that any such recognition of another normative system is only to be permitted if it does not break the nexus between sovereignty and territory.

For the majority in Yorta Yorta, the most salient consequence of the assertion of sovereignty by the British Crown was that the normative system which existed prior to the assertion of sovereignty could not thereafter validly create new rights. Rights or interests in land created after sovereignty and which owed their origin and continued existence only to a normative system other than that of the new sovereign power would not be given effect by the legal order of the new sovereign. This is so because the assertion of

44 See generally, C. Schmitt, "The Land Appropriation of a New World", above n.41.

45 It is this history that Hart's genetic account of modern law repeats and that the High Court renders axiomatic.

46 Mabo, above n.4, 36. 
sovereignty by the British Crown necessarily 'entails' that there could be no parallel law-making system in the territory over which it asserted sovereignty. If only a sovereign order can make law, and post-sovereignty there is only one (the new) sovereign order, it then follows, according to the logic of the majority, that the only rights or interests in relation to land or waters originating otherwise than in the new sovereign order are those that find their origin in pre-sovereignty law and custom. ${ }^{47}$ Laws and customs can only have meaning if they continue on, as an entailment of those laws and customs prior to the acquisition of sovereignty by the British Crown. ${ }^{48}$ While there is a certain order to this argument, it ignores the history of the common law's own relationship to other 'normative systems'. It also ignores the reality for many indigenous Australians who lived, some for over a century or more, according to their own laws, unaware of the imposition of this new legal regime over the land, and unaware that they no longer had internal law-making capacity. It also ignores those who continue to live by other laws that those of the Australian legal system. Finally, it also means that the judgment fails to properly deliberate on the central doctrinal issue of the case: how the rights of native title can recognise indigenous law and custom, let alone its evolution and change.

If there can be no parallel-law making, what then is the status of these laws and customs? What happens to these normative systems? Once (arguably for the majority) legal in nature, what becomes of them post-sovereignty? This is never directly addressed. Rather, the majority speaks of rights and interests and of an "identified body of law and customs" that are the creatures of a particular society that exists as a group and which acknowledged and observes those law and customs (axiomatically and empirically). ${ }^{49}$ Then it is claimed that in order to exist rights and interests must continue to be acknowledged and observed. ${ }^{50}$ Despite the use of the phrase 'traditional laws and customs', there can only be one legal system. What was 'law', post-sovereignty is now custom. Again while the majority represent such a situation as axiomatic, or as fact, such an approach has is in accordance with that of the early modern common law dealings with land in colonial Ireland.

While the entire story of the legal settlement of Ireland cannot be related here, it may be remembered that in the Case of Tanistry, referred to by Brennan $\mathrm{J}$ in Mabo (No. 2), it was held that the laws of the Irish had been 'abolished' on establishment of the common law. Further, any remaining indigenous interests in land could only be recognised if they could be proved

47 Yorta Yorta (HC), above n.3, 560-1.

48 The majority decision is suffused with a rhetoric of property: consider also the 'chain of possession' metaphor: ibid., 562. The language of the possession of rights and interests is run into the language of common law proof of title to property.

49 Yorta Yorta, ibid., 553.

50 In the Hartian model of observance the transition has sacral overtones: customs, as primary rules are taken up in the formation of a legal system through the 'union' of primary and secondary rules structured around a sovereign order of norms. See generally Hart, The Concept of Law, above n.30, Ch. 5. 
under the usual rules by which custom was established. ${ }^{51}$ These were continuity, reasonableness, and existence since time immemorial (i.e. before British sovereignty). While the parallels with Yorta Yorta are obvious, The Case of Tanistry considered these questions as ones of custom rather than an axiomatic consequence of sovereignty.

The principle that there can be no parallel law-making renders it difficult to envisage how the changes and evolutions of these customs that inevitably must occur in the wake of white occupation could be reflected in native title. While the majority denies that customs and traditions are 'frozen', its formulation of custom and tradition as tied to pre-sovereign formations inevitably lead towards a native title which is disarticulated from the normative system in which the High Court claims it is sourced. In one jurisdiction law and tradition change and evolve. In the other, they remain tied to an earlier era.

In sum, the High Court - with the aid of its jurisprudence - has reproduced questions of law and history as axiomatic categories and reported them as fact. It has turned both Australian and Aboriginal law into questions of factual reporting. Aboriginal law is not recognised as 'law', by the Australian legal system but as custom. Any understandings of custom and tradition must, for the majority, be formulated in the shadow of its own sovereignty. The talk of sovereignty and a sovereign order of norms by the majority of the Court has also displaced other important juridical concerns: notably that of jurisdiction. It is the High Court's conflation of sovereignty, in particular territorial sovereignty, with jurisdiction that allowed the majority to hold out the position of acknowledging indigenous normative systems on the one hand, and denying their contemporary efficacy on the other.

\section{Jurisdiction}

While the phenomenon of territorial sovereignty has, as outlined above, been with us for some time, the conflation of jurisdiction with sovereignty and territory is relatively new. As legal historians are well aware, $19^{\text {th }}$ century courts did worry about the limits of jurisdiction. Despite the Judicature Acts, the common law has never entirely removed itself from its origins as a jurisdictional institution. It was not until the end of the $19^{\text {th }}$ century that sovereignty, people and territory became one as a legal category. Yet the notion of jurisdiction clearly shadows the majority judgment in Yorta Yorta. Only missing is the discipline of jurisdiction, substituted by the phrase 'normative orders'.

While it has been axiomatic for common law jurisprudence that a nation can only have one sovereign order, it has also always been a feature of 'our' law that more than one jurisdiction or body of law (normative system if you will) can co-exist within that order. Until the seventeenth century a plethora of bodies of law co-existed in England. As that time, as Prest puts it:

51 The Case of Tanistry (1608) Davis 28, at 31-32; 80 ER 516, at 519-520. For the English translation see Sir John Davies, A Report of the Cases and Matters in Law, Resolved and Adjudged in the King's Courts in Ireland, Dublin, Printed for Sarah Cotter, under Dick's Coffee House, in Skinner Row, 1762, 78, 87. On this point see S. Dorsett, "'Since Time Immemorial': A Story of Common Law Jurisdiction, Native Title and the Case of Tanistry", above n.6. 
"There was little ... coherent about that fragmented chaos of overlapping (and frequently conflicting) jurisdictions national, regional and local courts, ecclesiastical and secular courts, courts occasional and permanent, courts dispensing English common law, Roman civil law, canon law and a bewildering variety of local customary law, courts of considerable antiquity and courts newly erected or asserted, courts swamped with business and courts moribund for lack of suitors." ${ }^{2}$

These overlapping and contradictory jurisdictions continued to be a feature of the English legal landscape for the next two centuries. Although many did fall into disuse, by the time of the settlement of Australia there were still numerous jurisdictions operational in England. In the late eighteenth century, at the time of the importation of the common law into Australia, that body of law was still only one of many. As Arthurs points out, in this period there were still over three hundred local courts which exercised civil jurisdiction, as well as arbitrators, domestic tribunals and administrative tribunals. Many of these courts did not apply common law, but administered distinctive sub-systems of local and special law. Altogether these bodies disposed of many more cases than the Westminster Courts. ${ }^{53}$

On importation to New South Wales, the common law became, at least as far as the colonists were concerned, the pre-eminent law of the new colony. Further, it was no longer split between the three central common law courts and other local courts as in England, but in fact achieved a degree of centralisation which was not be accomplished in England until the reforms of the late $1800 \mathrm{~s}$. It was, of course, not the only body of law to be imported. It is easy to forget that both equity and admiralty jurisdiction were also operational in early Australia.

Nor was it clear from the outset that these bodies of English law would be the only law of the colony. Contrary to Brennan J's assertion in Mabo (No.2) that the common law became the "law of the territory (and not merely the personal law of the colonists)", ${ }^{54}$ there was an initial spate of cases in which it was recognised by the Supreme Court of New South Wales that common law did not automatically apply to Indigenous Australians. ${ }^{55}$ These judgments were rendered in the language of jurisdiction. Did the common law courts have jurisdiction over Indigenous Australians? In Ballard, for example, although Forbes C.J. described Aboriginal institutions were

52 W. Prest, "Lawyers", in W. Prest, (ed.), The Professions in Early Modern England (1987), 65.

53 See generally H. Arthurs, "Special Courts, Special Law: Legal Pluralism in Nineteenth Century England", in G. Rubin, D. Sugarman, Law, Economy and Society: 1750-1914: Essays in the History of English Law (1984).

54 Mabo (No.2), above n.4, 36.

55 See, for example, $R$. v Ballard, unreported decision of the Supreme Court of New South Wales, 13 June 1829 , per Forbes CJ and Dowling J. A transcript of the notebook of Dowling J has been provided by B. Kercher, in (1998) 3 A.I.L.R. 412. The notebook is to be found at Proceedings of the Supreme Court, Vol.22, Archives Office of New South Wales, 2/3205, 98; $R$. v Lowe, unreported decision on 18 May 1827, reported in the Australian, 23 May 1827. This case can be found at 〈www.law.mq.edu.au/scnsw>. 
"shocking ... to our notions of humanity and justice", he was not prepared to find that the common law courts had "cognisance" of a crime committed by one Aboriginal upon another. ${ }^{56}$ Forbes C.J. came to the same conclusion several years later in $R$. v Boatman or Jackass and Bulleyes. ${ }^{57}$ Similarly, in Bonjon, Willis $\mathrm{J}$ found that the common law had no jurisdiction over crimes committed by Aborigines inter se. ${ }^{58}$ According to Dowling $\mathrm{J}$, in the Boatman case, the question of whether there was jurisdiction over the aboriginals was "a subject . . . of deep importance to the colony". 59

For common lawyers trained in England in a time when a number of jurisdictions still co-existed with the common law, it was clear that the relations between bodies of law was a matter of jurisdiction. Further, it was not axiomatic that only one body of law could exist under the body of singular sovereignty. For these early judges it was possible to envisage a legal order in which multiple jurisdictions existed in one physical space. In other words, sovereignty did not 'necessarily entail' that there could only be one law-making system. Nor was Australia the only jurisdiction in which this position was reached. In a similar period courts in Canada, New Zealand and the United States reached similar conclusions. All recognised the continuance of indigenous laws, despite the acquisition of sovereignty by the British. ${ }^{60}$

Despite this beginning, by the mid-nineteenth century, the common law settled down into a comfortable uniformity. In contrast to these early cases, later judges determined that Aboriginal law was not law. ${ }^{61}$ Once aboriginal law was determined not to be law, it became axiomatic that the common law (along with equity) was the law of the colony. ${ }^{62}$ Once this unitary view of the common law had taken hold, the language of jurisdiction, evident in the early Australian cases, simply died away. There were no multiple bodies of law. Therefore, there was no longer any need to understand or conceptualise the relationship between them in any terms, let alone those of jurisdiction. In Australia, from the mid-nineteenth century the language of jurisdiction was reserved for questions concerning the jurisdiction of a particular court, or for

56 ibid., at 413-4.

57 R. v Boatman or Jackass and Bulleyes, J. Dowling, 23 February, 1832, Proceedings of the Supreme Court of New South Wales, Vol. 64, Archives Office of New South Wales, 2/3247, available at 〈www.law.mq.edu.au/scnsw>.

58 R. v Bonjon (1841), published in (1998) 3 A.I.L.R. 417. This report is based on that of the Port Philip Patriot of 20 September 1841. It was also published in the Port Philip Herald of 21 September 1841. See B. Kercher, " $R . \vee$ Ballard, $R$. v $R$. Murrell v Bonjon" (1998) 3(3) A.I.L.R. 410.

$59 R$. v Boatman or Jackass and Bulleye, 10 Feb. 1832, Supreme Court of New South Wales, J. Dowling in J. Dowling, Select Cases, Archives Office of N.S.W., 2/3466, reproduced at 〈www.law.mq.edu.au/scnsw>.

60 See Connolly v Woolrich (1867) 17 R.J.R.Q. 75, 1 C.N.L.C. 70 (Que. S.C.), affd. sub nom. Johnstone v Connelly (1869) 17 R.L.R.Q. 266, 1 C.N.L.C. 151 (Que. C.A.); The Queen (on the prosecution of McIntosh) v Symonds, above n.7; Cherokee Nation v Georgia, above n.7; Worcester v Georgia, above n.7.

61 See, for example, $R$. v Cobby (1883) IV N.S.W.R. 355.

62 See, for example, Attorney-General v Brown (1847) 1 Legge 312, 318; Randwick Corporation v Rutledge (1959) 102 C.L.R. 54. 
conflicts of laws problems. The notion that jurisdiction attached to bodies of law was lost. ${ }^{63}$

The decision to recognise native title in Mabo (No. 2) was conducted without any reference to the notion of jurisdiction, or even to the fact that the recognition of native title itself 'necessarily entailed' a recognition of other (non-common law) bodies of law. Rather, the unitary view of law built up over the previous century was not only maintained, but reinforced. Terra nullius, arguably never a doctrine of Australian law until that case, ${ }^{64}$ was overthrown, but no mention was made of the indigenous legal systems which must therefore have existed if Australia was in fact not a legal vacuum. This position became, however, increasingly hard to maintain, culminating in the discussion by the High Court in Yorta Yorta of 'other normative systems'.

Throughout the High Court decisions since Mabo (No.2), the language of the court has continued to be that of sovereignty, not jurisdiction. In Mabo (No.2) itself, questions of sovereignty were raised in the context of the British Crown's acquisition of the continent of Australia. This in itself says nothing about the internal ordering of that sovereign nation. However, subsequent cases have been at pains to reinforce that as sovereignty resides in the Australian nation, there is only one law of the land: the common law (of Australia). ${ }^{65}$ This understanding confuses the need of the ordering of modern states to point to a supreme internal legal authority with authority and the capacity to decide and determine within a limited sphere. As outlined above, multiple jurisdictional authorities have long been recognised within the tradition and history of the common law as compatible with single sovereignty. ${ }^{66}$

If it is accepted that multiple jurisdictional entities are no threat to sovereignty, the 'normative orders' acknowledged in Yorta Yorta can be identified as jurisdictional entities: bodies of law which co-exist with the common law under the auspices of the one sovereign nation. ${ }^{67}$ It also becomes far from axiomatic that the intersection between these jurisdictions and the common law took place only once. As discussed, typically, within common law such intersections have been understood and justified - made just - in terms of the history of an institutional and conceptual practice. The common law historically co-existed with many other bodies of law, but reserved to itself the authority - jurisdiction - to determine the ways in which rights in that other jurisdiction would be recognised and enforced

63 See P. Rush, "Deathbound Doctrine: Scenes of Murder and its Inheritance", (1997) 16 Studies in Law, Politics and Society 71.

${ }^{64}$ For an excellent analysis of the chimera of terra nullius see D. Ritter, "The "Rejection of Terra Nullius" in Mabo: A Critical Analysis", (1996) 18 Syd.L.R. 5.

65 See, for example, Walker v New South Wales (1994) 69 A.L.J.R. 111; Coe v Commonwealth (1993) 68 A.L.J.R. 110.

66 A modern example is the ongoing recognition of the autonomy of the laws of Native American Nations. This includes both the capacity to make laws, and to make judicial determinations with respect to these laws. It also includes some legal capacity over non-indigenous peoples who live on Native American land. Such legal autonomy is not seen as inconsistent with the sovereignty of the United States.

67 Or, for that matter, parallel bodies of law or jurisdictions that are recognised by the common law without engaging questions of sovereignty linked to territory. 
within its own sphere. In contemporary terms: the common law can co-exist with indigenous laws, but asserts the jurisdiction to determine the limits of recognition and enforcement of rights from that other jurisdiction within itself. $^{68}$ Further, historically, this was never a 'once and for all' recognition. Intersections (to use the High Court's language) happened not once, but on an ongoing basis. Autonomous bodies of law co-existed with the common law. Only when a conflict occurred would rights and interests be determined - according to the shape they had at that time, not at some arbitrarily determined earlier time.

Finally, if the court's vision of one unitary legal system is allowed, then however native title is categorised, it must also be recognised as a creature of the common law of Australia or, if it is preferred, the Australian legal system and its norms. If the Court recognises only one sovereign territory and one jurisdiction, any affirmation of law must be a part of the Australian legal order by way of that recognition. The complex mechanisms of recognition are a part the Australian legal system and its jurisdiction. The act of recognition of 'laws and customs' - of taking authority to exercise a jurisdiction - is an act of law. Recognition of custom is a part of long established common law practice that can be traced back at least as far as the colonial settlement of Ireland and the Case of Tanistry. Quite apart from misrepresenting the legal history of the common law, the insistence that the link between sovereignty and territory is an axiomatic fact and not the work of jurisdiction, both denies the possibility of giving an account of other jurisdictions (or normative orders) within Australia and prevents there being any coherent account of the Australian common law settlement of the nation.

In Yorta Yorta both the majority and the minority acknowledge the existence of other 'normative systems' but whereas the majority simply deny the lawmaking capacity of indigenous normative orders post-sovereignty, the minority confine themselves to stating that the common law is limited to recognition and protection of 'native title', which in turn owes its existence to these other normative systems. The problem with such an approach is that while it does not specifically deny the authority and law-making capacity of indigenous normative orders, it leaves them in limbo, failing to accord them any status and failing to articulate any way of understanding the relationship between the common law and these normative orders. As a result, both the majority and minority displace questions of jurisdiction: the majority by denying the capacity of any aboriginal jurisdiction to function postsovereignty and the minority by, in essence, acknowledging aboriginal jurisdictions (native title derives from traditional laws and customs which continue to evolve and adapt post-sovereignty) and then ignoring these jurisdictions.

This section has examined some of the ways in which the judgment of the majority in Yorta Yorta has produced an account of its own jurisdiction. It has done so by staging the legal settlement of the land of Australia in terms of a succession of laws. Once the British Crown asserted sovereignty, the 'traditional laws and customs' of aboriginal peoples cease to be the laws of the territory except in so far as they are acknowledged by the laws of the

68 See M. Hale, (C. Gray, ed.), The History of the Common Law of England, and An Analysis of the Civil Part of the Law (1971) (1713). 
Australian legal system and its ordering of questions of sovereignty, law, custom and territory. What was gained, for the majority, was an evidential measure of the recognition of aboriginal laws framed in terms of the following of tradition. In the absence of an analysis of jurisdiction what is rendered opaque is the possibility of establishing an intersection of laws as opposed to an assumption or subsumption of earlier law. ${ }^{69}$ This still leaves open the question of whether the High Court in Yorta Yorta managed to maintain the order of its own jurisdiction.

\section{Authority and Jurisdiction}

The insistent message behind any native title claim is that there is another, parallel, legal ordering to what is presently the recognised law of territory of Australia. In Yorta Yorta the majority repeated the formula of Mabo (No.2): questions of sovereignty were not justiciable, there is no other law of the territory. They also treated as a fact that there is only one sovereign jurisdiction over the territory of Australia. Earlier parts of this essay have considered the effects of the first claim on the second. Here some comments will be made about the representation of authority and authorship of these laws and the account of responsibility that is engendered.

The most direct use of jurisprudence made by the Court would appear to be in the polemical formulation of the authority of the Australian legal system. The majority decisions in Mabo (No.2) were notable for seeking to found the authority of the Court at some distance from the State, perhaps in the domain of human rights, a spiritual relation to land, or even the feeling of the community. ${ }^{70}$ These grounds in a sense might be viewed as part of the inheritance of a natural rights jurisprudence. The Court did so, it was suggested in Mabo (No 2), in response to the injustice of the settlement of Australia, or at least some of it. In the end, however, in Mabo (No.2) the High Court positioned itself not as the defender of natural right but as the guardian of the common law of Australia. ${ }^{71}$ By contrast the High Court in Yorta Yorta has gestured towards a state order of law both in its insistence that native title is now to be understood solely as a product of legislation, and in its formulation of sovereign jurisdiction.

The tradition of positivist jurisprudence that Hart naturalised as ordinary legal language does at least have the merit of insisting that legal authority be articulated in terms of a concrete order of domination articulated through a territorial and ascriptive concept of state. ${ }^{72}$ It also has the merit of aligning current High Court authority with its own institutional history: in whatever way common law and State government might be related, the law of the colonies in Australia had a firm basis in requirements of Imperial government. The task and function of British colonial and then Australian Commonwealth government has not been primarily moral but statist: the concern has been with the establishment and maintenance of civil power and civil order. The operational medium of such power was not moral but

69 For analytical account of this predicament see Rush, above n.63, 79-86.

70 For example Mabo (No.2), above n.4, 33 on international law and human rights (Brennan J); ibid., 61 on natural law (Deane And Gaudron JJ).

71 ibid., 68-69 on the difference between the common law and acts of State.

72 See for example, D. Saunders, The Anti-Lawyers, Routledge, 1999, Ch. 1. 
political-legal. A State-based jurisprudence at least offers a clear site or position from which the High Court can articulate its laws.

In Mabo (No.2) one consequence of trying to ground law in ethics was the displacement of both the force of law and the juridical order of representation. In order to ground the common law in contemporary values of human rights and contemporary understanding of history, it was necessary to dis-aggregate reason of state and common law. In so doing the Court could provide little account of the exercise of authority in relation the practices of its own jurisdiction. ${ }^{73}$ The majority in Yorta Yorta have realigned the common law with state sovereignty but have still struggled to develop any account of their jurisdiction. ${ }^{74}$ However the uses to which Hart's jurisprudence were put in the judgment seem designed as much to deflect as to assert such claims of authority. Having raised questions of jurisprudence, of the experience and use of law and custom, the majority then denied that the "jurisprudential questions that [they] have identified" are of import. ${ }^{75}$ They further announced that despite the foregoing discussion of Hart and Austin, it may not be productive or fruitful to even attempt to "search for parallels between traditional law and traditional customs on the one hand and Austin's conception of a system of laws, as a body of commands or general orders backed by threats which are issued by a sovereign or subordinate in obedience to the sovereign." 76 Not to search for parallels in a common law legal order that might once have claimed to judge by reason of analogy, or by finding parallels, might suggest a loss of faith in legal order.

It might be imagined that such an account of the authority of law would sensitise the High Court to the fact that what was at issue in Yorta Yorta was the manner in which to address itself to another law. Given the analysis presented in this essay the use of jurisprudence by the majority in the High Court seems to have distracted itself from giving any account of the internal jurisdiction of the government of law. In figuring the relation between territory and other laws as ones of fact or evidence of the continued recognition (or not), the internal ordering of the common law has itself been reduced to a reiteration of the 'ordinary meaning' of legislation. Beyond this the character of the performance of sovereign authority remains unarticulated by the High Court. McHugh's plaintive comments in Ward (and again in Yorta Yorta) about the inability of the common law to provide redress for indigenous claimants remain as an appeal to moral conscience and responsibility rather than a call for responsibility for the order of law. ${ }^{77}$

73 See Rush, above n.6, 146-150.

74 It is possible that for the minority this question was confused with the appropriate uses of legal resources to interpret the Native Title Act 1993.

75 Yorta Yorta (HCA), above n.3, 552.

76 ibid., 551.

77 "The dispossession of the Aboriginal peoples from their lands was a great wrong. Many people believe that those of us who are the beneficiaries of that wrong have a moral responsibility to redress it to the extent that it can be redressed. But it is becoming increasingly clear - to me, at all events - that redress can not be achieved by a system that depends on evaluating the competing legal rights of landholders and native-title holders. The deck is stacked against the native-title 


\section{CONCLUDING COMMENTS}

In this essay attention has been given to the ways in which the High Court has represented its own laws and jurisdiction. If Mabo (No.2) can be interpreted as having re-established, albeit in a minimal manner, a technology of jurisdiction that recognised the continuation of other 'laws and customs' within a territory, the majority in Yorta Yorta can be taken as having given sharper emphasis to questions of jurisdiction by figuring issues of aboriginal 'laws and customs' as being concerned with the intersection of laws. However, as the analysis presented here has attempted to show, these questions of jurisdiction have been limited - if not entirely effaced - both in terms of the authority and authorship of law and in terms of the specific relationship between sovereignty, territory and land. The majority in Yorta Yorta in effect refused to offer an account of its jurisdiction except by displacing the intersection of laws on to the moment of a past assertion of sovereignty. In this sense the High Court has not yet touched on the possibilities of recognising a parallel or intersecting legal order. It has simply refused itself permission to recognise such a possibility. (In all this the High Court has handed down a sorry judgment.)

The purpose of this essay has not been to establish the general grounds of a critique of legal order but to follow the jurisdictional ordering of a legal judgment that directly addresses the legal settlement of Australia. If there are generalisations to be made from this analysis it would be in terms of the repetition of a number of gestures of jurisdictional delimitation: the persistence of common law refusal of recognition of the status of indigenous laws; the importance of the internal ordering of the technologies of recognition; and the restricted articulation of the modes of authorisation of law. The consideration of jurisdiction here has also raised at various points a number of linkages between jurisdiction and responsibility. ${ }^{78}$

Finally if a decision were made to develop a juridical understanding of the settlement of Australia, the possibility of re-settlement, postcolonial or otherwise, would continue to depend on the relationships of jurisdiction, if not also sovereignty and territory. This is so regardless of the constitutional formation of the state polity. ${ }^{79}$ It would remain a matter of responsibility for the technology or discipline of a jurisdiction.

holders whose fragile rights must give way to the superior rights of the landholders whenever the two classes of rights conflict.": Ward, above n.8, 156-7. These concerns can be contrasted with those of Callinan J. Contrary to McHugh J, he recognises responsibility and points out in detail the ways in which the dispossession of indigenous people restricts and prevents the recognition of their laws and customs: ibid., 591ff. See S. Zizek, "Superego by Default", (1995) 16 Cardozo Law Review 925 for comments on authorship of laws.

78 For example, M. Weber, 'Politics as Vocation' in H. Gerth and C.W. Mills (eds.), From Max Weber: Essays in Sociology (1947).

79 C. Douzinas, "The Metaphysics of Jurisdiction" in S. McVeigh, (ed.), Jurisprudence of Jurisdiction, forthcoming (1995). 